\title{
An Action Research on the Effectiveness Uses of Flash Card in Promoting Hijaiyah Literacy among Primary School Pupils
}

\author{
Muhamad Zahiri Awang Mat ${ }^{1}$ \\ Siti Salwa Md. Sawari² \\ Noriza Mat Nawi ${ }^{3}$ \\ Faridah Junit ${ }^{4}$ \\ Mislinah Mohd Othman 5 \\ 1,3,4,5 Kulliyah of Education, International Islamic University Malaysia \\ ${ }^{2}$ Faculty of Islamic Civilization, Universiti Teknologi Malaysia.; Email: ${ }^{1}$ zahiri@iium.edu.my
}

Doi:10.5901/mjss.2016.v7n2s1p433

\begin{abstract}
Hijaiyah literacy skills is important for every primary school pupil in learning Islamic education subject a foundation to enable pupils to read lqra and mastering reading the Quran. This study aimed to identify the effects of flash cards use in improving Hijaiyah literacy among primary school pupils. The study was conducted in three schools around the state of Selangor and the Federal Territory of Kuala Lumpur. The subjects were 41 pupils in a class who are in counselling lqra 'of the three schools. An action research design was used in this study. In order to observe the objective, researcher used observation and oral test. The results showed that, the use of flash cards able to increase pupils' Hijaiyah literacy. Flash card is encouraged to be used among primary teacher because it helps weaker pupils to recognize letters and bragged single hijaiyah more easily and effectively.
\end{abstract}

Keywords: Flash Card, Islamic Education, Quranic Teaching, Method of teaching.

\section{Introduction}

Islamic education aims to produce good and civilized individuals, who believe and practice with their knowledge, capable of taking responsibility as a servant of Allah and His khalifah to build own self, family, community and country physically, spiritually, emotionally and intellectually based on Islamic principles restate from the Quran and the Sunnah (Muhaidi et, all. 2016a). The Quran is an important source in the life of Muslims (Muhaidi, Mohd Al'Ikhsan, Siti Salwa 2015a, 2015b, Siti Salwa, Muhammad Zahiri 2013; Muhaidi et, all. 2016b). Quranic education is one of the educational field aims to build a righteous and just society based on love, compassion, brotherhood, tolerance, responsibility, open-minded, democracy without cruelty, modest and follows according to Quranic guidelines (Ahmad Mohd Salleh, 1997). The main objective of Islamic education is to educate people in this globalized world to devote themselves to Allah. Learning and memorizing the Quran will be able to form Islamic minds that will create a generation of hafiz, religious, dai'e and professional, and this meets the goals of Quranic education(Muhaidi, Mohd Al'Ikhsan, Siti Salwa 2015c).

Beyond the modern world today, the young generation must be educated and trained to love the Qur'an so that their life will be blessed by Allah s.w.t (Muhamad Zahiri, Siti Salwa, Zarqo', Siti Zuraidah, 2015).Thus, a teacher should strive to teach (Siti Salwa, Muhammad Zahiri \& Mohd Al'Ikhsan, 2014) and disseminate knowledge related to the Quran well enough in order to improve the pupils' quality of reading the Quran, including strengthening the basic literacy skills like recognizing the single letters of Hijaiyah starting from primary one.

Hijaiyah letters are the Arabic letters consist of 29 letters starting with alif letter and ending with ya letter. These letters can be read with only 3 lines which are called "fathah" or upper line, "kasrah" or bottom line and "dhommah" or front line. In the Quranic lesson, firstly, the pupils must be able to remember, identify, recognize and articulate all 29 letters correctly to enable them to read Iqra ' 1 book until Iqra' 6 book and they can read the Quran fluently afterward.

Children must be introduced with hijaiyah letters in their life as early (Azlina, Norazura Ezuana, Siti Salwa, 2013, Supriyadi. n.d). as possible similarly when their parents introduce them with roman letters so that they can recognize and pronounce hijaiyah letters very well and later on, they can read the Quran fluently and correctly. 


\section{Flash Cards as Teaching Aids}

Flash cards are one of the effective medium in educational world which represent the visual resources, it is neither a new trend nor recent idea. Flash cards and teaching is correlated and it is an approach of ensuring the teaching process becomes a meaningful learning to pupils. Throughout years, there are many studies which being conducted related to flash cards and teaching. A study conducted by Ode (2014) shows that that the use of teaching aids have significant influence on the teaching and learning in secondary schools at Makurdi, Nigeria. However, Ode (2014) gave attention to the use of flash cards in teaching which does not completely deny the important role in using it, but in a general manner since its focus more on kinds of audiovisual means. According to Klasone (2013) who study about pictures when teaching prepositions in English lessons, he found that flashcards are most suitable teaching aids for representation of a single concept, such as an object or an action."

Overall, the direct instruction flashcards were not very effective for the participant, but the reduction of the set size and time per session showed a slight increase in performance (Kane et al, 2015). Based on Mansourzadeh (2014), the used of flash can able to enhance students ability in learning English language -According to Harris et al. (2015) when flashcards were employed in learning, students participations will increased." Kane et al. (2015) and Harris et al. (2015) both focusing on direct instruction flash cards in teaching, but differ in terms of participants and subject or course involved.

Moreover, Bechtolt et al. (2014) also study about direct instruction flashcards in teaching, but focus on developmental disabilities pupils. Based on Romjue et al. (2011) discover that flashcards were effective in increasing sight word reading among students Besides, Glover et al. (2010) mentions that flash card is suitable and affordable teaching aids for teachers. Furthermore, according to Pfaff et al. (2013) math racetrack and instruction using flashcards and were effective in increasing the accuracy, fluency and retention in learning language.

In addition, result from another study concludes that flash card can contribute towards the improvement of vocabulary learning among pupils(Komachali \& Khodareza, 2012). Apart from that, Rokni and Karimi (2013) found that, the effective way for learning vocabulary is through flash cards. Study of Rokni and Karimi (2013) focus on the using of the flashcard and real objects in representing the visual instruction. In short, the previous study had found many benefits in using flash card as medium of instruction between teacher and pupils regardless of subjects in educational realm.

\section{Research Objective}

This study aimed to identify the effects of flash cards use in improving Hijaiyah literacy among primary school pupils. Specifically;

1. To identify the significant different result before and after pupils used flash card in reading Jawi.

2. To examine the significant different result of Jawi proficiency before and after pupils used flash card.

3. To investigate the ability of flash cards in improving Hijaiyah literacy among primary school pupils.

\section{Focus of the Study}

This study focused on the skills of recognizing the single letters of Hijaiyah. This study is very important to be implemented in order to realize the objectives of achieving pupils' proficiency in recognizing hijaiyah letters and reading Iqra' 1 until Iqra 6 books fluently and correctly. If they are unable to master these skills, it is difficult for them to read the Quranic verses which are quite difficult to read. This situation will give negative impacts toward themselves and they will continuously consider the Quran as a tough lesson to learn and lose their interest in learning. It will become more challenging as they will continue facing problems in Quranic lesson in the next few years. Therefor, this study was done to identify the effects of flash cards use in improving Hijaiyah literacy among primary school pupils.

\section{Methodology}

\subsection{Observation}

Observation is one of the research methods used to obtain the research results. Observation is also an alternative in collecting information or data besides questionnaire and interview. Through observation, researchers can observe the behaviour of a subject based on identified variables. The role of the researcher is to observe the changes in behaviour, from a far or close distance. By using this method, the researcher or observers have to observe the samples within 
particular time. In this study, observation was carried out during Iqra' 1 reading activity in the Quranic lesson. This process is carried out through stages involving two pupils only to get the accurate results. Pupils were required to read Iqra' 1 book and their reading have been recorded. During their reading activity, the teachers have identified the letters that the pupils were unable to articulate. The reading results of the pupils were also evaluated to identify the pupils' level of proficiency in identifying single hijaiyah letters.

\subsection{Oral examination}

Oral exam is the process of questioning and answering directly between a teacher and his pupils. Question and answer activity is also a method to determine the pupils' mastery level in a particular subject. This process has been done gradually by questioning pupils individually through the use of "flash card" of single hijaiyah letters. Pupils will be asked by the teachers who showed the "flash card" randomly. Through this method, the teachers were able to know the pupils' mastery level of single hijaiyah letters precisely.

\subsection{Sample of the Study}

A sample of seven pupils of Year 1, Ulu Yam Lama Primary School, Batang Kali consists of three females and four males, 16 pupils of SJK (C) Kwong Hon Sg Besi consists of nine males and seven females and 18 pupils of Sungai Besi Primary School consists of ten males and eight females were selected. All of them were 41 pupils. They have a low proficiency level in Quranic lesson in which they were unable to recognize the single Hijaiyah letters completely and have difficulties in reading Iqra' 1 book fluently.

\section{Findings}

Based on the results on the use of "flash card" which was given to 41 Year 1 pupils to take home and will be asked by the teachers during the next day to articulate the letters until they can master and recognize the letters, it can be deduced that the "flash card" helped pupils to remember difficult letters accurately and consequently, they were able to read Iqra' 1 to Iqra' 6 books fluently and recite the Quran correctly.

\subsection{The reading test of Iqra '1 (difficult articulated letters) before and after}

Table 1: The reading test of Iqra 1 result before and after

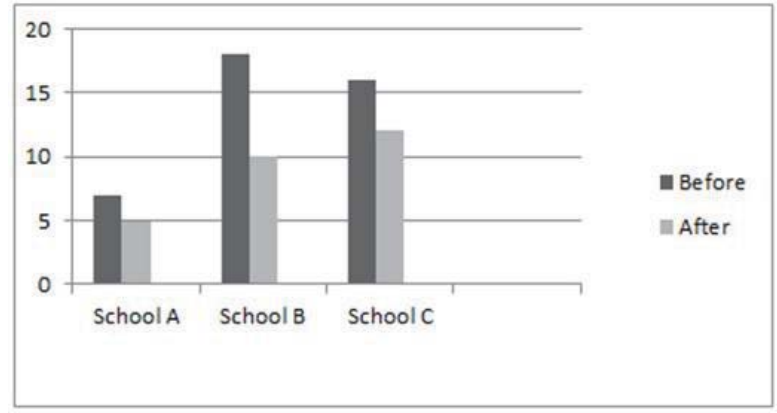

Before the used of flashcard in learning, it was found that 41 pupils failed to regcornize Hijaiyah letter. However the result change after Flashcard being introduced. Table 1 above, indicated that 5 out of 7 pupils from the School A were able to

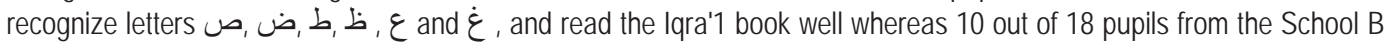
were also able to recognize the letters pupils of School $\mathrm{C}$ have shown positive changes after being given flash cards of single hijaiyah letters. 


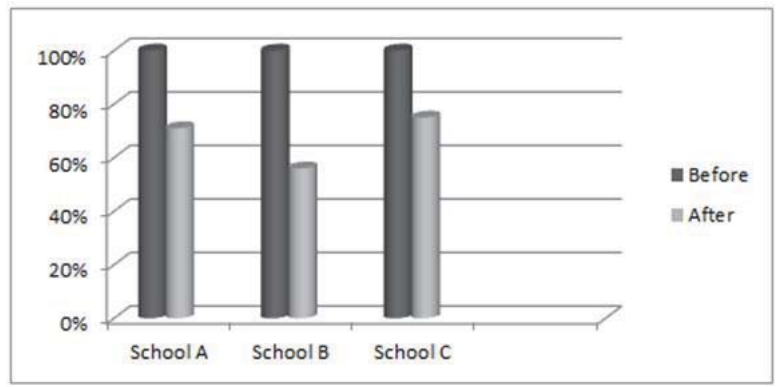

Figure 1: Pupils' reading proficiency level

Figure 1 above shows the pupils' reading proficiency level who could articulate the single hijaiyah letters randomly. It has been found that $71 \%$ pupils (5 out of 7 ) of School A were able to articulate and recognize single hijaiyah letters shown randomly by their teachers in which they were not fully mastered before. Besides, $76 \%$ pupils (10 out of 18) of School B were able to articulate the letters shown by their teachers at random correctly where they were not fully mastered before. Similar with the performance of pupils in School $\mathrm{C}$ in which $75 \%$ pupils (12 out of 16) were able to master or articulate the single hijaiyah letters shown randomly where they were not fully mastered before.

\subsection{The percentage of pupils who have and have not mastered lqra '1 book}

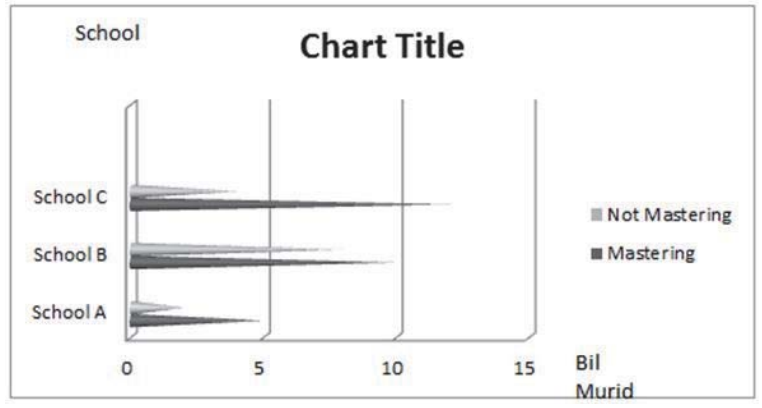

Figure 2: Percentage of pupils who have and have not mastered

According to Figure 2 above, only 2 out of 7 Year 1 pupils of School A were unable to read Iqra' 1 book fluently. Meanwhile, 8 out of 18 pupils of School B were still unable to read Iqra' 1 book fluently. In School C, only 4 out of 16 pupils have not mastered Iqra' 1 book. Based on the above Figure, it can be concluded that the use of "flash card" can help to improve Iqra ' 1 reading skills and recognize single hijaiyah letters.

Based on the main research objective, it is clear that "flash card" application has helped pupils to improve their mastery of recognising single hijaiyah letters. Pupils were given the opportunity to take the flash cards to their home as drills and enrichments. From that method, they can improve their understanding and avoid confusion in recognizing single hijaiyyah letters effectively. Although pupils from SJK (C) were facing difficulties because of time constraints with only 2 hours a week compared to National Primary Schools (SK) which have 3 hours a week besides burdened with tuition and a lot of school work, the use of "flash card" is one way to help pupils to recognize some difficult and confusing single

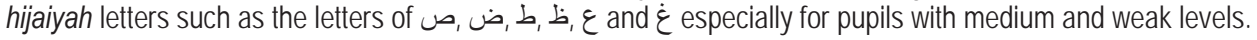

\section{Data Analysis}

It has been proven that the use of "flash card" in schools and giving pupils flash cards to bring back to their homes have given favourable findings. Of 41 respondents, 27 of them have successfully improved in which they have successfully 


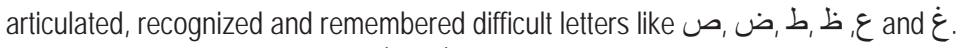

According to Haliza \& Joy (2009), teaching and learning process is no longer a teacher-centered learning but it is a student-centered learning either individually or collectively. Giving pupils flash cards to bring back to their homes as drills is an example of student-centered learning. Pupils were given the opportunity to have their own enrichment exercises monitored and cooperated by their parents.

\section{Conclusion and Recommendation}

During the study on the challenges in identifying and remembering single hijaiyah letters among Year 1 pupils, this research has prompted that the weak pupils should be given more attention than other pupils. Teachers should always be critical, creative and innovative in their teaching session. The use of "flash card" really helped pupils to become more familiar and easy to remember the hijaiyah letters. Cooperation from parents is also important in the effort to improve their ability to recognize and remember single hijaiyah letters so that their children are able to read Iqra ' 1 book and the Quran afterwards, very well. After this, it is hoped that teachers can provide beautiful "flash card" in order to attract pupils' interest in the Quranic lesson generally, and particularly, able to read Iqra '1 book fluently. The use of "flash card" has

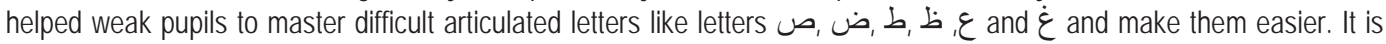
hoped that the use of "flash card" can be used by teachers to both excellent and weak pupils who are interested in learning the Quran, especially the Iqra '.

\section{References}

Glover, P., McLaughlin, T., Derby, K. M., \& Gower, J. (2010). Using a direct instruction flashcard system with two pupils with learning disabilities. Electronic Journal of Research in Educational Psychology, 8(2), 457-472.

Rokni, S. J. A., \& Karimi, N. (2013). Visual instruction: an advantage or a disadvantage? What about its effect on EFL learners' vocabulary learning?. Asian Journal of Social Sciences and Humanities, 2(4), 236-243.

Erbey, R., McLaughlin, T. F., Derby, K. M., \& Everson, M. (2011). The effects of using flashcards with reading racetrack to teach letter sounds, sight words, and math facts to elementary pupils with learning disabilities. International Electronic Journal of Elementary Education, 3(3), 213-226.

Pfaff, E., McLaughlin, T. F., Neyman, J., \& Everson, M. (2013). The effects of direct instruction flashcards with math racetrack with addition facts for an elementary school student with ADHD. International Journal of Basic and Applied Science, 2(1), 124-130.

Komachali, M. E., Khodareza, M. (2012). The effect of using vocabulary flash card on Iranian pre-university pupils' vocabulary knowledge. International Education Studies, 5(3), 134-147.

Romjue, H. R., McLaughlin, T. F., \& Derby, K. M. (2011). The effects of reading racetracks and flashcards for teaching of sight words. Academic Research Journal, 1(2), 134-146.

Bechtolt, S., McLaughlin, T. F., Derby, K. M., \& Blecher, J. (2014). The effects of direct instruction flashcards and a model, lead, test, procedure on letter recognition for three preschool pupils with developmental disabilities. Journal on Developmental Disabilities, 20(1), 5-15.

Harris, M., Helling, J., Thompson, L., Neyman, J., McLaughlin, T. F., Hatch, K., \& Jack, M. (2015). The effects of a direct instruction flashcards system to teach two pupils with disabilities multiplication facts. International Journal of Applied Research, 1(3), 66-70.

Mansourzadeh, N. (2014). A comparative study of teaching vocabulary through pictures and audio-visual aids to young Iranian EFL learners. Journal of Elementary Education, 24(1), 47-59.

Kane, C., McLaughlin, T. F., \& Mortensen, S. (2015). The effects of DI flash cards with and without match to sample with edibles on number recognition using reduced set size and DI discrimination training: a case report. International Journal of Multidisciplinary Research and Development. 2(1), 224-231.

Klasone, I. (2013). Using pictures when teaching prepositions in English lesson in the form 3- 4. Journal of Language and Literature of Education, 8, 23-38.

Muhaidi Hj Mustaffa Al Hafiz, Mohd Al'Ikhsan Ghazali, \& Siti Salwa Md. Sawari. (2015b). Eksplorasi Hubungan Hafazan Al-Qur'an Dan Kecemerlangan Para Pelajar Maahad Tahfiz Al-Quran Wal Qiraat Pulai Chondong. Prosiding Seminar Antarabangsa Isu-Isu Pendidikan [Translate: Explore Relationship memorizing the Quran and Excellence Students Tahfiz Institution Al-Quran Wal Qiraat Pulai Chondong. Proceedings of the International Seminar on Education Issues] (IsPEN2015), Kolej Universiti Islam Antarabangsa Selangor. 8-9 Jun 2015.

Muhaidi Mustaffa Al Hafiz, Siti Salwa Md. Sawari, \& Mohd Al'Ikhsan Ghazali. (2015c). Pengurusan Kualiti Pendidikan: Aplikasi Terhadap Strategi Hafalan Sistematik [Translate: Education Quality Management: Application to Memory Systematic Strategies]. 2nd International Convention on Islamic Management . Academy Islamic Studies. University of Malaya. 4-5/11/2015.

Muhamad Zahiri Awang Mat, Siti Salwa Md. Sawari, Zarqo' Bt Ahmad Mustakim \& Siti Zuraidah Bt. Ab Rahman (2015). Teaching Aids As Effective Approach In Teaching Jawi Among Primary School Student. Proceedings of the $6^{\text {th }}$ International Conference on Southeast Asia, University of Malaya, Kuala Lumpur, 2-4 December 2015. Faculty of Arts and Social Sciences, University of Malaya. UM PRESS, University of Malaya, Kuala Lumpur. Pp430-433. 
Siti Salwa Md. Sawari, Muhammad Zahiri Awang Mat. (2013). Harmonizing Al Qabisy's View And Practice Of j-Qaf Programme In Malaysian Primary School. Asian Journal Education Management and Science 2(11):.

Azlina Mustaffa, Norazura Ezuana Bte Najid, Siti Salwa Md. Sawari, (2013). Students' Perceptions and Attitude towards the effectiveness of Prezi Uses in learning Islamic Subject. International Journal of Advanced Studies in Computer Science and Engineering (IJASCSE), 2 (6): 51-57. 5 January 2014.

Ode, E. O. (2014). Impact of audio-visual (AVs) resources on teaching and learning in some selected private secondary schools in Makurdi. International Journal of Research in Humanities, Arts and Literature, 2(5), 195-202.

Buku Manual Kajian Tindakan Edisi Ketiga.(2008).Putrajaya:Bahagian Perancangan dan Penyelidikan Dasar Pendidikan Kementerian Pelajaran Malaysia.[Translator: Putrajaya: Planning and Policy Research Division of Education Ministry of Education Malaysia]

Rosinah Edninin (2012), Penyelidikan Tindakan Kaedah Dan Penulisan - Edisi Kedua, Freemind Horizons Sdn. Bhd. [Translate: Action Research Methods and Writing - Second Edition, Freemind Horizons Sdn. Bhd.]

Supriyadi. (n.d).Pembelajaran membaca dan menulis permulaan dengan metode Iqro bagi siswa kelas awal sekolah dasar. Jurnal Filasafat, teori dan praktik kependidikan. [Translate: Learning to read and write beginning with Diana method for the early grades of elementary school students. Journal of philosophy, theory and practice of education]

Siti Salwa Md. Sawari, Muhammad Zahiri Awang Mat, Mohd Al'Ikhsan Ghazali. (2014). Nurturing The Enthusiasm and Ideals of Teachers Through Reflective Ibnu Jama'ah's Book: Tazkarat As-Same Wa Al-Mutakillim Fil Adab Al-Alim Wa Al-Muta'allim. . 5th International Graduate Conference on Engineering Science \& Humanity 2014. 21st -22nd August 2014.

Muhaidi Hj Mustaffa Al Hafiz, Mohd Al'Ikhsan Ghazali, \& Siti Salwa Md. Sawari (2015a). Transformasi Pendidikan Hafazan Al-Qur'an Dari Zaman Awal Islam Hingga Kini. Prosiding Seminar Antarabangsa Isu-Isu Pendidikan [Translate: Transforming Education memorizing Qur'an Early Islamic Period Until now. Proceedings of the International Seminar on Education Issues](ISPEN2015), Kolej Universiti Islam Antarabangsa Selangor. 8-9 Jun 2015.

Muhaidi Mustaffa Al Hafiz, Muhammad Fathi Yusof, Mohd Al'Ikhsan Ghazali, \& Siti Salwa Md. Sawari (2016a). Descriptive Qualitative Teaching Method of Memorization in The Institution Of Tahfiz Al-Quran Wal Qiraat Pulai Condong And The Students' Level Of Academic Excellence. Mediterranean Journal of Social Sciences, 7(1 S1).

Muhaidi Mustaffa Al Hafiz, Muhammad Fathi Yusof, Mohd Al'lkhsan Ghazali, \& Siti Salwa Md. Sawari (2016b). Historiography of Quranic Memorization from the Early Years of Islam until Today. Mediterranean Journal of Social Sciences, 7(1 S1). 